\title{
METAPHORICAL VERBALIZATION OF THE CONCEPT WOMAN IN THE VICTORIAN NOVELS OF MARY BRADDON
}

\author{
Olena NOVOSADSKA \\ Chernivtsi Yuriy Fedkovych National University, Ukraine
}

\begin{abstract}
The representation of women in the written texts of the Victorian Era has received a great deal of attention and critics have analysed different strategies used for the description of women in novels. This paper looks at a particular device employed by the Victorian novelist Mary Braddon in the representation of women, namely, the use of conceptual metaphors. Women and metaphors alike are at once meditational and relational. A woman serves to mediate between man and man, man and Nature, man and Spirit. The research deals with repeated metaphors presenting women in the guise of foods, animals, babies, parts of the body, members of the aristocracy and supernatural creatures. Bearing in mind the social force of metaphor in our understanding of the world and of ourselves as well as the important role language plays as a channel through which ideas and beliefs are transmitted and perpetuated, the present study attempts to offer a preliminary exploration of how images of women are transmitted and perpetuated by the Victorian novelist Mary Braddon through linguistic metaphors.
\end{abstract}

Keywords: woman, Victorian Era, stylistic devices, images

The final two decades of the Victorian era witnessed the beginning of a shift in social attitudes regarding gender relations, which is marked by a steady movement away from the pattern of patriarchal male supremacy and female dependence towards the modern pattern of gender equality. Such changes, nevertheless, were illustrated in the Sensation novels of the 1860s and although the Sensation novel spends quite a bit of time detailing women's problems without resolution, it was the recognition that gender inequality existed that ultimately led to future changes and development. The previous attitudes regarding women's suffrage by the end of the nineteenth century were finally 
being "vigorously rejected" and the Sensation novel with all its thrills and excitement helped to accelerate the understanding of the political and power struggles of the female sex. Throughout the nineteenth century, the portrayal of woman as a wife and/or mother dominated the female characters in many popular works as well as serious works of literature. Even Sensation novels, with their flawed women characters, depict the ideal woman as a wife, mother, and loyal companion to her spouse. It is when women deviate from these established norms that they are depicted as villainous and often punished by either other characters or by fate (Marcus 34-41).

The Sensation novel was a genre particularly noted for its unconventional depiction or handling of women. "Unconventional" means departing from the conventional depiction of women in Victorian Literature - as angels, upholding the morality and sanctity of the Victorian homes, or as passionless madonnas who submerged their own desires and interests in those of their husbands or children. It was however a usual custom in the Sensation novels to depict at least one female protagonist as an assertive and transgressive creature of passion, a woman cleverer than Victorian society expected its women to be and adept in disguise and deception. In a few words she was someone dangerous to know, usually the transgressive and self-assertive woman, juxtaposed with the 'angelic' heroine. Such women were doubly dangerous as they generated social instability, because they had secrets potent enough to destroy the fabric of rigid Victorian society. Such juxtaposition of two contrasting characters of women was an important feature of the Victorian novel in general, a stylistic device to depict the two polarities of the moral and ideological spectrum that women occupied - the angel or the fallen (Gilbert and Gubar 5-9).

The nineteenth-century novel was one of the most important cultural sites for representing and shaping ideas about women. Mary Elizabeth Braddon's novels were considered "middlebrow" and were very popular in Victorian England. Along with this facet, her heroines were considered controversial because they were not portrayed as what would be labelled a "proper female" in Victorian society. She knew that she was departing from Victorian moral and social codes, but she chose to challenge the convention and create heroines of her own in addition to exposing the corrupt social climate of the time, perhaps another reason why she was not accepted, until recently, into the literary community and still fights for legitimacy among so many Victorian novelists. The popularity of her novels, her heroines, along with facets of her personal life, keep her from being recognized as one of the foremost authors in the Victorian period (Donnelly 70). The Question of the Woman, raised by Mary Braddon in her novels, influenced the mid- and late-Victorian feminists. The New Woman in her novels was intelligent, educated, emancipated, independent and self-supporting. The New Woman novels often expressed dissatisfaction 
with the contemporary position of women in marriage and in society, and represented female heroines who fought against the traditional Victorian male perception of woman as 'angel in the house', challenging the old codes of conduct and morality.

Mary Braddon created literary works that shook traditional conventions in Victorian England by showcasing the feminist view so clearly and refuted the denial and ignorance of women's sexual identity and passion. To captivate and satisfy readers, Mary Braddon used metaphors to represent women in the most favourable light. Through metaphors, this novel sets up a different universe. Thus, Mary Braddon showed that women are capable of being passionate, resisting the limiting conventions of her time to reach their goals - a life in fulfillment and bliss.

Metaphor is everywhere in literature, from the interrelations among its smallest (words, images, figures of speech) to its largest (characters, plot, narrative) elements. Beyond the most basic assumptions about metaphor - that it has a primarily decorative purpose, to make writing more "exciting" or "beautiful"; or that it helps the reader "visualize" images; or that it serves to highlight and heighten important themes - lie great areas of thinking about metaphor, which can help deepen and clarify our understanding of literature, art and life.

The function of metaphor in literature is twofold. The first, and more practical, function is to allow the reader greater understanding of the concept, object, or character being described. This is done by comparing it to an item that may be more familiar to the reader. The second function is purely artistic: to create an image that is beautiful or profound or otherwise produces the effect that the writer desires. For these reasons, writers have used metaphor since the earliest recorded stories (Black 35). As Gerard Steen suggests in his article "Metaphor: Stylistic Approaches", throughout centuries there have been different views as to what the role of metaphors in literature in fact is. Citing a work written at the beginning of the 1980s dealing with the rhetorical devices in literature, he writes that in that book "metaphor is included in the section on tropes, together with metonymy, synecdoche, and other figures of speech defined by "strange meaning" or "semantic deviation" (Steen 51). This suggests that even among scholars analyzing metaphor use there were discrepancies in the perception of the role of this figure of speech in literature, not to mention the fact that they were not concerned with the analysis of metaphor use in any other type of discourse.

In the most recent history of literary studies, that is in the second half of the 20th century, numerous changes of perception of the nature and role of metaphors in literature occurred. Steen indicates that according to views perceived as valid prior to the emergence of cognitive linguistics and the new approach to the study of metaphorical expressions, metaphors were seen merely 
as a rhetorical phenomenon. In the 1960s many scholars believed that metaphors involved some kind of grammatical deviance, while in the 1970s the famous philosophers John R. Searle and H. P. Grice argued that comprehending metaphors requires pragmatic inferencing, a view subsequently abandoned by cognitive linguists (Steen, 53). Moreover, changes in the perception of metaphorical expressions by different scholars led to partial explications of their nature, use and importance, but at the same time to certain differences in the very definition of metaphors. Not all linguists unanimously agreed on the definition of metaphors as suggested by cognitive linguists and as a result, in the stylistic and literary analyses there are now at least three definitions of this phenomenon:

1. The restricted rhetorical definition of metaphor as active or deliberate metaphor;

2. The broader cognitive-linguistic definition focuses on metaphor as "a specific linguistic form", whether it is active or deliberate;

3. The most encompassing cognitive definition, which defines metaphor as a cross-domain mapping in conceptualization that may be realized by various rhetorical figures, of which linguistic metaphor is one that has to be contrasted with simile, analogy, and so on" (Steen 53).

According to Ellen Winner there are two kinds of use of metaphors in literature. The first one is the spontaneous and the second one is the intentional use of metaphor. Spontaneous use of metaphor happens when authors use metaphors automatically to support certain ideologies while intentional use happens when they use these metaphors according to their needs. The second one is the most important, because these metaphors provide visual descriptions of concepts (80). Literary metaphors stand out - they strike us as distinctly moving or aesthetically pleasing - not because they differ in essential form or function from metaphors in other areas of language; on the contrary, metaphors in literature make use of the rudimentary architecture of common, automatic and deeply engrained conceptual metaphors. Authors and poets do, however, frequently set about extending, elaborating or combining ordinary, non-literary metaphors in deliberate and unusual ways (Lakoff \& Turner, 67-72). By exploiting the basic metaphorical tools we use in everyday speech and writing, these artists guide us toward new and nonautomatic modes of thought, which remain all the while meaningful and readily understandable. Thus, metaphor enables authors and poets to exercise creativity and readers to access their meanings. Literary metaphors can transport a reader into exotic, uncharted conceptual realms while retaining a firm tether to familiar territory. A literary metaphor may be entirely novel but it will resonate with us because it maintains the structure of underlying, conventional conceptual metaphors.

There are several ways that literature can cause us to become aware of metaphor. A literary metaphor may make use of a conceptual element in the 
source domain that the conventional mappings do not typically or frequently tap, it may introduce to the source domain an entirely new but conceptually consistent element, or it may manipulate an existing one in some novel fashion (Kövecses, 48). Perhaps what chiefly distinguishes a literary metaphor is its function in probing, questioning and challenging the common uses of the metaphor itself. By highlighting, rejecting or reversing aspects of a metaphor that we otherwise take for granted, an author or poet encourages his reader to examine the appropriateness of that metaphor and its role in shaping cognition and behavior.

In our paper, we are going to look at examples selected from the novels Aurora Floyd and Lady Audley's Secret by Mary Braddon, in which metaphors are used, and in so doing are imaging the woman. In these novels Braddon vividly pushes gender boundaries and teaches us that women of the lower classes have "to take shortcuts" to obtain social status and material possessions that others acquire by their fortunate birthrights.

Lady Audley's Secret is probably Braddon's most renowned novel. It tells the story of an enchanting twenty-year-old governess, Lucy Graham, who temporarily succeeds in climbing the social ladder by tying the knot with Lord Audley, a wealthy and distinguished elderly man. She is, in fact, Lucy Talboys, who has changed her name to Lucy Graham to be a governess to two girls in London. When she is a governess to two daughters of a neighboring house, Sir Michael Audley falls in love with her and proposes to her. She accepts and becomes Lady Audley.

A former governess - in herself a problematic borderline figure between social classes, constantly shifting from the public to the domestic domain (Wetzel 80), Lady Audley is introduced on stage playing the part of the quintessential Victorian icon. Metaphors in the novel help to reveal the heroine's character. She is endowed with a delicate, almost "fragile figure" (78), "the innocence and candour of an infant" (68) beam in her charming and cheerful face and "shine out of her large and liquid blue eyes" (43). Her golden ringlets gleam in the sunlight and make a "pale halo round her head" (9). She seems so pure that she "might have served as a model for a mediaeval saint", "she can charm with a word or intoxicate with a smile" (171) while other times, she is compared to "a Madonna in an Italian Picture" (207). Fond of her piano, "happy as a child surrounded by new and costly toys" (43), this "babyfied little creature" (111) feels a strong aversion to reading and studying, while she enjoys society and being admired. Once settled into Lord Audley's lavish mansion, she immediately establishes herself " the belle of the country, pleased with her high position and her handsome house; with every caprice gratified, every whim indulged" (43).

Lured by the prospect of a newly-acquired wealthy life, Lucy willingly accepts to be considered an ornament in Lord Audley's "Aladdin's palace" 
(234). She is associated with and surrounded by dazzling and high-priced commodities that, while perfectly framing her beauty (the woman's only asset), at the same time seem to suffocate her. Consequently, Braddon often lingers on the metaphoric portrayal of her character's fur coats (86), "silks and velvets" (303), expensive wardrobe (whose open doors reveal "the treasure within" [56]), "fragile teacups of turquoise china" (234), "ivory-backed hairbrushes" (56), "gilded mirrors, shimmering satin and diaphanous lace" (234). Yet, the atmosphere in the lady's apartments is stifling, "almost oppressive from the rich odours of perfume bottles whose gold stoppers have not been replaced" (56). As the writer seems to imply, dualism and ambiguity are not just expressed through her devious villainess; they pervade the very core of Victorian society: the domestic hearth.

Over and over again, Lady Audley is compared to"a deceitful enchantress", an "amber-haired siren" (224), "an angry mermaid" (255), the chimerical creature joining human and animal traits "who got poor old Ulysses into trouble" (30). Her unwomanly physical strength is highlighted when she manages to throw George Talboys into a well, in the vain attempt to rid herself of the burden of her first family (it should not pass unnoticed that, in a most unmotherly fashion, she had already forsaken her son). Finally, the adjective "unnatural" is repeated seven times in a few lines, in order to describe her criminal behaviour and altered facial features when she conceives her arson plan to murder Robert Audley.

Playing her last part (that of the mentally deranged, insidious other), Braddon's devil is "buried alive" (303) in a madhouse, meaningfully located in a foreign country, more suitable to her "snake-like" personality and infectious disposition than healthy Britain: in Belgium, "the sibilant French syllables hiss through her teeth as she utters them, and seem better fitted to her mood and to herself than the familiar English she has spoken hitherto" (310). She says to Robert Audley that "he has brought her to her grave" (315). Even Lucy's dreams of social ascent are turned into nightmares in the mental asylum and, once more, commodities signify the dreadful change: her "costly mirrors" are replaced with "wretched mockeries of burnished tin", and instead of the precious drapery and elaborate furniture adorning Lord Audley's mansion, she is surrounded by "the faded splendour of shabby velvet, and tarnished gilding, and polished wood" (309). Incidentally, before leaving for Belgium, she had tried to hide vases of Sèvres and Dresden, jewels, and golden drinking cups among the folds of her dresses, carefully packed in her trunk: "her mercenary soul hankered greedily after the costly and beautiful things of which she had been mistress" (304).

Lady Audley undergoes a change from activity to passivity. She was active enough to achieve what she wants. When she is exposed, she is condemned and punished and she should be buried alive. In other words she is to be passive for the rest of her life. This has been the crime of a person who has 
been active and has transgressed and trespassed where angels fear to tread. What she did was because of her poverty and poverty is the root of many problems for many people. It is poverty that makes deception beautiful to Lady Audley. From a feminist point of view her transgressive behaviour might be seen as a feminist performance, where she gets around patriarchy and turns patriarchy on its head

This clear-cut distinction between sanity and perversion, between the angel protectively sheltered in the household sphere and the diabolic female criminal undermining social stability and customary gender roles, is strikingly blurred and problematised by Mary Elizabeth Braddon in her 1862 novel Lady Audley's Secret. As this essay sets out to demonstrate, through the histrionic character of Helen/Lucy/Lady Audley, the disquieting devil in the house, whose immaculate, childlike looks artfully concealed her "evil-minded intentions", the writer wished to expose the limits of the male-fabricated construct of Victorian womanhood.

Ellen Miller Casey suggests that "in her sensation novels, Braddon sees through Victorian propriety to a counterworld of feminine rebellion" (81). The reason for this rebellion is woman's alienation. Therefore Lady Audley secretly changes her alienation into violent ways of manipulation. Jennifer Watson believes that Lady Audley "does not rant and rave in the manner that traditional insanity implies. Instead, her actions are programmed and surreptitiously implemented with a singularity of purpose." (164)

Aurora Floyd is another Victorian Sensation novel by Mary Braddon, which tells the story of the young lady of the same name. Focusing upon Aurora Floyd, Braddon constructed a similar character to that of Lucy Audley, with some glaring differences, the most important being hair colour. The depiction of hair colour was extremely important to Victorians. They believed it instantly gave an insight into a person's nature. Women with fair/blonde hair were more likely to be innocent and amiable, those with dark hair (like Aurora) were thought to embody the passionate and dangerous woman. Instead of the goldenhaired so called angel Lucy Audley, the reader is introduced to the boisterous, tempestuous, dark-haired Aurora: "the thick plaits of her black hair made a great diadem upon her low forehead and crowned her an Eastern empress" (82), " looking at him with her eyes flashing forked lightnings of womanly fury" (104). Aurora displays no submissiveness to any men, despite her flaws, and instead continues to exercise dominion over them, exemplifying the presence of female authority in a patriarchal society: "it was Aurora's eyes that overawed all her kinsfolk" (7). Aurora is even compared to other powerful women of history, namely Cleopatra of Egypt and Hecate of Greek mythology: "this imperious creature, this Cleopatra in crinoline" (20). However, Aurora's authority almost tells the readers it is acceptable to rise against society and defy rules that they have lived by for centuries. Braddon also portrays Aurora as a beautifully enticing creature, with reference to her fierce, immobilising eyes and medusa- 
like hair. Incidentally, later in the novel, a further association is made between Aurora's sexuality and the mythical medusa as Aurora naps on a sofa with "masses of ebony hair uncoiled and falling about her shoulders in serpentine tresses which resemble blue-black snakes released from poor Medusa's head." $\underline{(56)}$

Braddon's fictional heroine is complex, one who is loyal to her father and is, therefore, in many ways submissive, while simultaneously knocking down the doors of convention and societal expectation. Braddon quickly eradicates any perception of Aurora as pure and passive by underlining her qualities that are associated with manliness. Aurora is greatly intrigued with horses, and she has been accustomed to riding since childhood. Such pleasures were not feminine pursuits, and we are shown how bewildering and uncommon this was for the woman of the Victorian period. Thus, from the very beginning it is clear that her unladylike fondness for horseback riding and racing, her masculine and unrefined passion for sport and the turf are Aurora's form of rebellion against the restricted Victorian image of femininity which sought to equate passivity with purity.

Aurora's remoteness from the "ideal woman" can further be seen in Bulstrode's comparison of Aurora to Luce - her cousin and the model of the gentle, passive, and submissive Victorian woman - " "she seemed an angel, descended from the skies" (235). While Bulstrode is fascinated by Aurora's beauty and her strong character, he notes how pure and simple Lucy is, how she would make the perfect wife: "she was just the good creature....purity and goodness had watched over her"(86); beauty which really doesn't need adornment" (94); "her hair wanted the sunshine gleaming through it to light up the golden halo about her face" (104). Aurora, on the other hand, is described as full of passion and aggressiveness. Aurora is encompassed with "beautiful fury" (134) as Braddon describes the heroine's act of violence, which displays her passion and aggression. Thus Braddon paints a picture of "a woman in the full flush of her beauty and prosperity" (7) - a woman who is clearly different from the Victorian ideal.

Despite the fact that Aurora 'loses the fight' and in the end has to give in to the pressures of society - the effect that such novels had on actual women was very much the opposite. In fact Victorian women began to rebel against convention through reading sensation novels that indirectly voiced women's ambitions for individuality and power (Kane, 48). The heroines of novels voiced the necessity of transformation in regard to women's property rights, the need for better education and jobs, and change in marital relations. The New Woman began to emerge (Perkin, 241). And it was this very emergence of the New Woman that was partly responsible for the uprising of feminism that fought to question women's traditional roles. Thus revolutionary ideas that are stated brilliantly in anti-revolutionary form of the 1860's sensation novels can be 
credited with placing in the foreground the issue of female subordination, and laying the foundation for the partial female acceptance and equality that we enjoy in our society today.

\section{Conclusions}

Thus, language is of a metaphorical nature. The metaphors used in literature provide software to conceptualize the world in better and broader ways. Metaphors are important because they provide a visual description about something or some idea. Metaphors are not only limited to language but they control our thoughts, feelings and ideas. It shapes our way of thinking about world. In reviewing the metaphors above, we can see that, through the ambiguous character of Lucy, the charming, attractive, clever, cunning fallen angel in the house, and Aurora, the boisterous, tempestuous creature, they unquestionably succeeded in challenging one of the central assumptions of patriarchal power: the fabrication of Victorian womanhood.

\section{Works Cited}

Black M., More about Metaphor, Cambridge, Cambridge University Press, 1993.

Braddon, M. E., Lady Audley's Secret, Ed. Jenny Bourne Taylor, London, Penguin, 1998.

Braddon, M., Aurora Floyd, New York, Harper \&Brothers, Publishers, 1863.

Carnell, J., The Literary Lives of M. E. Braddon: A Study of Her Life and Work, Hastings, Sensation Press, 2000.

Donnelly, B., "Sensational Bodies: Lady Audley and the Pre-Raphaelite Portrait" in The Victorian Newsletter Issue 112, 2007.

Gilbert, S. and Susan Gubar, The Madwoman in the Attic: The Woman Writer and the Nineteenth-Century Literary Imagination, Yale, 2000 (second edition).

Lakoff, G. and Johnson, M., Metaphors We Live By, London, University of Chicago Press, 1980.

Lewis, D., Women Writing Men: Female Victorian Authors and their Representations of Masculinity, Ball State U, 2011.

Marshall, G., Victorian Fiction, London and New York, Arnold and Oxford U. P., 2002.

Kövecses, Z., Metaphors of Anger, Pride, and Love: A Lexical Approach to the Study of Concepts, Amsterdam, John Benjamins, 1986.

Searle, J., Metaphor. In Metaphor and Thought, A. Ortony (ed.), Cambridge, Cambridge University Press. 1979.

Sharon, M., Between women: friendship, desire, and marriage in Victorian England, New Jersey, Princeton University Press, 1966.

Tilley, E., "Gender and Role-Playing in Lady Audley's Secret" in Tinkler, V. V., et al. eds., Exhibited by Candlelight: Sources and Developments in the Gothic Tradition, Amsterdam, Rodopi, 1995. 


\section{BIONOTE}

Olena NovosadsKa is a PhDstudent in the Department of Communicative Linguistics and Translation, Chernivtsi National University, Ukraine. Her research interests are cognitive linguistics and cognitive science .She has published in numerous journals and in various collections of scientific works. Among her latest articles are "Semantic and cognitive aspects of the concept WOMAN" in Scientific Journal of Drogobych National University,Ukraine; "The concept of frame and the framing process" in Society for cultural and scientific progress in Central and Eastern Europe, Budapest. She is currently working on her PhD thesis:" The concept of WOMAN in the Victorian Era". Email: novosad.elena88@gmail.com 